\title{
The Mediating Effects of Brand Preference to Customer Satisfaction
}

\author{
Jasin Mochammad ${ }^{1}$, Dytta Novrianda ${ }^{2}$, Pudji Astuti ${ }^{3}$, \\ C.C. Widayati ${ }^{4}$, A.Z. Arifin ${ }^{5}$ \\ ${ }^{1}$ Islamic State University, Syarif Hidayatullah, Jakarta, Indonesia \\ ${ }^{2}$ University of Pancasila, Jakarta, Indonesia. \\ ${ }^{3}$ University of Borubudur, Jakarta, Indonesia. \\ ${ }^{4}$ Universitas Mercu Buana, Jakarta, Indonesia. \\ ${ }^{5}$ University of Tarumanagara, Jakarta, Indonesia. \\ email: moch.jasin1@gmail.com
}

\begin{abstract}
The purpose of this study is to analyze the influence of brand preference to customer satisfaction (advertiser). Samples consists of one hundred and twenty persons of decision makers of government advertisemen programs in various government agencies and state owned companies. Data was collected by using self-completed questionnaire. Structural Equation Modelling used to analyze the indicator variables, latent variables and measurement error variables to determine of causal brand awareness, brand association, brand extension, perceived quality to customer satisfaction through brand preference of Sindo Media (MNC Group). The finding reveals a significant influence on mediated variables. While Brand awareness, Brand association, Brand extension, Perceived quality, has a significant influence on customer satisfaction. That means Brand preference has significant influence to customer satisfaction.
\end{abstract}

Keywords: Brand Awareness, Brand Association, Brand Extension, Perceived Quality, Brand Preference dan Customer Satisfaction.

\section{INTRODUCTION}

The development of a media convergence pattern that has recently been embraced by a number of national press companies seems to be closer to the pattern mentioned by Grant and Wilkinson (2009), which includes technological convergence, multimedia content, ownership, collaboration, and coordination. The same thing done by Group Media Nusantara Citra (MNC) in doing trobosan connection with media convergence that is by giving birth media platform consisting of print media, electronic and online media which synergy and incorporated in Sindo Media. According to MNC Group CEO, Hary Tanoesoedibjo, quoted from Okezone. "Sindo Media has a specificity in terms of content. Each integrated media platform also includes local elements, while still promoting informative content and little entertainment. "

According Dimmick (2003: 4) the survival of a mass media industry can not be separated from the source of life support like a living creature. For the media industry, the source of their life support, namely capital (advertising revenue), types of content (media content), and the types of audiences (the kind of audience). Based on the concept of media ecology, basically the media industry fight over the three supporting resources. The higher the similarity of support, the higher the competition. 
Competition among mass media said Picard in Albaran (1996: 3) said the mass media is an economic institution that connects between production and disseminate media content to consumers. Consumers in the media bussiness here is the audience, the consumer is an important component in the economy.Audiences that influence media companies with media content on offer. Kosumen sets value based on individual desires and specific product needs. This process helps consumers to determine the type of media content that can be useful to meet their needs (Albaran, 1996: 22).

In addition to consumers, the business of mass media economy is also influenced by advertising revenue on a media, because the mass media will not be able to survive without the income from advertising.

Picard in Albaran (1996: 27) explains that the unique media industry can be seen from its function as a dual product market, meaning that although the media company producing the product but their role in the two parts of the market for goods and services. Fields of goods produce newspapers, magazines, radio, tv, books, or movies. The goods are then marketed to consumers and will be evaluated differently. The second market is media companies doing activities with the sale of advertising. The advertiser will reach the audience through the content offered by the media.

Based on the above background, researchers will conduct research related to integrated media marketing strategy one of which Sindo Media which is part of MNC group in the face of other media competition that has the same business line in increasing the company's revenue through advertising.

\section{LITERATURE REVIEW}

Piccard in albaran (1996: 27) explains that the media industry has a dual function product market, which means that the media not only produce the goods but also play a role in the services market in this case is the sale of "Space" advertising. If it is associated with Dimmick opinion regarding the source of life support media that capital (the source of ad revenue), the type of content (the type of media content), and the type of audience (the audience). In marketing services, media (product) using a marketing strategy to reach a wide audience, which will take effect with advertisers who will use the space sold.

Each of these media have their respective strategies in marketing their products through the application of STP (segmentation, targets and positioning)which can reach a wide audience, as is done by Sindo Media, with target audiences in the class A and B based on the segmentation of the media focused media Special news so that the positioning of Sindo Media is as media news and informative. Mass media is no longer a channel for marketing communications for products that want to market products through mass media channels, but the media is also a product that can market itself to capture consumers (advertisers) and convince advertisers to conduct marketing activities through the media. Therefore it is essential for the mass media are pursuing the brand equity (brand equity).

Brand awareness in this study explained that the initial brand awareness is the foundation of customer knowledge about Sindo Media, where the level of brand awareness starting from the level of recognition ( brand recognition ), then enter the stage of reminders (brand recall) and reach the top of the minds of consumers. This stage of the brand began to be known and remembered,but of the many brands integrated media 
customers are expected to have greater knowledge about the brand Sindo Media ( brand knowledge ) and mastery of the brand are among brand competitors (brand domination) becomes very important for customers to increase brand recall . Furthermore, customers can argue about the brand used ( brand opinion ). Brand Opinion which will determine the extent to which customers can remember the brand Sindo Media among brands such as Kompas and Tempo.This is similar in the words quoted Aaker (Chieng Fayrene and Goi Chai Lee, 2011) for a new brand or a niche, recognition becomes important. Brand can be famous because the brand in mind and at the height of the customer's mind into something very sensitive and significant. Brand knowledge and opinions about the brand will become a benchmark for consumers considering a brand (brand recall).Brand knowledge and opinions about the brand will become a benchmark for consumers remember a brand ( brand recall).Brand knowledge and opinions about the brand will become a benchmark for consumers remember a brand ( brand recall).

Written by David Arnold and Addison-Wesley (1992: 142) if the line extension is successful then there are 3 main benefits derived from the expansion of the brand, namely:

1. When the familiar elements involved in messaging or positioning new brand new then there is an increasing likelihood of consumers. (We know that the new message is difficult to be accepted in the minds of consumers).

2. The new offer will refresh a brand that already exsist of group brand variations. This will increase the number of bids that are under the umbrella of brands ( umbrella brand) and improve its offering to kosumen.

3. Improved cost-effectiveness of the resources spent to support the family brand, as synergies benefit all lines in the achievement and reduce marketing costs.

The benefits of brand extension strategies include equity transfer brand of the parent brand to brand extension and brand extensions to the adverse effects of the parent brand (Keller: 2003). Another benefit of brand extension that is the reciprocal benefits given not only to the parent brand, but the category of the product or other expansion. While the loss of the expansion of the brand in general, ie because of inconsistent or their negative association of the brand extension to the parent brand.

Perceived quality is another dimension of brand value is very important to choose the goods and services bought Aaker (1991). Perceived quality is defined by Zeithaml (1988) as a judgment (perception) of consumers to the benefits of a product as a whole compared with its successor. From the above definition can be concluded that the perceived quality can be defined as the overall customer perception of quality or excellence of a product or the quality of services, with regard to what is expected by the customer.

Quoting from Ervan Seferi and Kweek CHong Ling (2013) perceived quality ( perceived quality) as the overall perception of the customers about the success of the quality of products or services compared with offerings from competitors.

Z eithaml (1988) and Erenkol and Duygun (2010) stated that the quality of the product is different from the perceived quality due to the perceived quality is an assessment of the subjective over the buyer of the product. The concept of quality is essentially relative, and depends on the perspective used. Basically there are three quality orientation, namely: (1) the perception of the consumer,(2) The products / services, and (3) process. For the third tangible product orientation can be distinguished, but for a product that is services, products and processes can not be distinguished because it could be the product is the process itself. According to Zeithaml (1988) confirms that the perception of quality can act as a key to influence in determining consumer choice. 
Every decision that a customer into buying a product are influenced by various factors, one of the factors that influence the purchase decision is a brand preference (brand Preference). Brand preferences are considered important for the company, because it is one indicator of customer loyalty and brand strength of each (Ya-Hui Wang: 2014) while the brand preferences according to Howard dkk quoted from the journal that published the Ya-Hui Wang said brand preference can be seen as attitudes that influence consumer purchase decisions, which then lead to behavioral tendencies which the buyer will choose a particular brand and other brands ignore.

While the concept of brand preference described by Mitchell \&Amioku 1985 quoted (Zahra Kashanizadeh: 2014) brand preferences as a set of attributes that lead to brand loyalty. These attributes are categorized into three categories: consumer attributes, attributes of products or services, and market attributes. Brand preferences according to Hellier, et al: 2003 in Margaretha, 2008) is the degree to which the consumer requires the services rendered by the company today as the comparison on services provided by other companies with a series of deliberations. So it can be concluded that brand preference is a factor that affects the consumer to choose the brand that corresponds to the desired, brand selection is based on a consideration of the attributes shown of the brand. Brand preference (brand Preference) the level of brand awareness where the brand is already on top of mind of consumers, just that companies need support services for consumer attributes compared to other companies (Hellier, et al: 2003, in Margareth, 2008). The same thing was reemphasized by Samadi: 2007 in Zahra Kashanizadeh: 2014) which states beliefs about product attributes affect consumer to consumer attitudes towards a particular brand and ultimately encourage the tendency of behavior and brand preferences.in Margareth, 2008).

The same thing was reemphasized by Samadi: 2007 in Zahra Kashanizadeh: 2014) which states beliefs about product attributes affect consumer to consumer attitudes towards a particular brand and ultimately encourage the tendency of behavior and brand preferences.in Margareth, 2008). The same thing was reemphasized by Samadi: 2007 in Zahra Kashanizadeh: 2014) which states beliefs about product attributes affect consumer to consumer attitudes towards a particular brand and ultimately encourage the tendency of behavior and brand preferences.

A strong brand preference has a degree of consumer preference on the brand, the company that developed the brand Preference properly will be able to face a competitor, a good preference to provide assurance about the quality of products / services rendered.

Connection in this study how a brand preference created Sindo Media is already able to convince and persuade consumers have a tendency towards the brand so that customers (advertisers) satisfaction of the Sindo brand compared to brands leading competitors such as the Kompas, and tempo.

Satisfaction and dissatisfaction of customers for a product or service as the end of a sales process provides distinctive impact to the behavior of customers for such products. The formation of attitudes and behavioral patterns of customers to purchase and use of products is the result of their previous experience. Customers who enjoy the product will develop attitudes that support the company (favorable). Conversely, if the product / service fails to bring performance and not according to what the customer expects, it will cause a negative impression about the products / services ( unfavorable ). Characteristics of attitude that is based on direct experience is an attitude that is usually adopted by the consumers with a greater level of confidence and stronger than seeing the advertising. 
Theoretically, Zeithaml et al say there are five dimensions of behavior (Creep, 2014: 239) are: loyalty / fidelity to the company (loyalty), the desire to move the product ( switch), the willingness to pay ( willingness to pay more), the response of the external environment on problem solving (external response to the problem ), and the response of the internal environment of the settlement of the problem (internal response to the problem ).willingness to pay more ( willingness to pay more), the response of the external environment on problem solving (external response to the problem ), and the response of the internal environment of the settlement of the problem (internal response to the problem ).willingness to pay more ( willingness to pay more), the response of the external environment on problem solving (external response to the problem ), and the response of the internal environment of the settlement of the problem (internal response to the problem ).

\section{METHOD}

This study of samples taken with consumers (advertisers) who never advertise in Sindo Media least 2x advertise. Samples to be tested are advertisers who are from the category of government (ministry, local government, or state-owned), because ads from this category has grown quite rapidly. As quoted (Marketeers.com, 2016) reports Nielsen Advertising Spending Growth in 2015, governments and political organizations are in first place as the largest advertising shopper reaches $\mathrm{Rp} 7.37$ trillion. This amount exceeds even any category ad spending on television. Another reason determining the sample in the category of government,Researchers see the government have a responsibility to disseminate information related to government performance and relation to the service to the wider community. So that needs publicity and communication activities undertaken significant and sustainable.

Analysis of the data using SEM models, according to Ferdinand (2006) the number of samples to be tested is between 100-200, or depending on the number of parameters / indicators used in all latent variables, ie the number of parameter multiplied by 5 to 10 . This study uses 21 indicators / parameter so using an estimate of the number of samples is 105-210 respondents. While the sampling method used is purposive sampling method ( purposive sampling ). Purposive sampling which aims to subjectively choose samples. This was done because researchers have examined that the information needed can be obtained from certain target groups who are able to provide the desired information for their own and meet the criteria specified by the researcher (Ferdinand, 2006).

Purposive sampling method chosen to determine the respondents representative of the research, respondents who referred to an advertiser from Sindo Media and the respondents never advertise in Sindo Media in the category of government. Respondents were defined by researchers as much as 105-210 respondents. Based on the calculation of respondents with an error rate of $5 \%$ of researchers, and questionnaires addressed directly to the respondents Sindo Media. Respondents were selected, namely those who work and are associated with public relations activities, information and community services in an organization of the Ministry / Institution State, local governments and state enterprises.

It is an analysis that is used to discuss and explain the results of research on a variety of symptoms or cases which can be described by using the particulars as measured by numbers and require clear and translation. Based on the variables measured in this study, this study used data analysis and processing techniques using Structural Equation Model 
(SEM) of a statistical package LISREL. Analysis using SEM techniques that SEM play a variety of roles, including as a system of simultaneous equations, linear causal analysis, path analysis ( path analysis ), analisys of covarianve structure and structural equation modeling. (Setyo, 2015). Research using SEM say Gujarati (1995, in Setyo, 2015:12) that provides simultaneous information on the causal relationships between the variables, as well as provide information about the load factor and errors of measurement.

Test matches and match more detailed examination can be summarized in the table according to Vitello (1997) quoted Setyo (2015) are as follows:

\begin{tabular}{|c|c|}
\hline GOF size & Compatibility level Acceptable \\
\hline \multicolumn{2}{|c|}{ ABSOLUTE-FIT Measures } \\
\hline Statistics Chi-Square $\left(\mathrm{X}^{2}\right)$ & $\begin{array}{l}\text { Following statistical tests relating to } \\
\text { significant requirements. The smaller } \\
\text { the better. }\end{array}$ \\
\hline Non-centrality parameter (NCP) & $\begin{array}{l}\text { Expressed in terms of the specifications } \\
\text { of the Chi-Square. The assessment is } \\
\text { based on a comparison with other } \\
\text { models. The smaller the better. }\end{array}$ \\
\hline Scaled NCP (SNCP) & $\begin{array}{l}\text { NCP expressed as the average difference } \\
\text { every observation in the context of the } \\
\text { comparison between models. The } \\
\text { smaller the better. }\end{array}$ \\
\hline Goodness-of-Fit Index (GFI) & $\begin{array}{l}\text { Values ranged from } 0-1 \text {, with higher } \\
\text { values are better value. GFI } \geq 0.90 \text { is } \\
\text { a good fit, while the GFI } \leq 0.80<0.90 \\
\text { was marginal fit. }\end{array}$ \\
\hline Root Mean Square Resdiual (RMR) & $\begin{array}{l}\text { Residual average between matrix } \\
\text { (correlation or covariance) were } \\
\text { observed, and the results of the } \\
\text { estimation. Standardized RMR } \leq 0.05 \text { is } \\
\text { a good fit.. }\end{array}$ \\
\hline
\end{tabular}

Root Mean Square Error of The average difference per degree of Approximiation (RMSEA) freedom which is expected to occur in the population and not in the sample. RMSEA $\leq 0: 08$ is a good fit, while RMSEA> 0.05 is a close fit .

Single Sample Cross-Validation Index / Used for comparison between Expected Cross Validation Index models. The smaller the better. In a (ECVI). single model, ECVI value of the model approaches the saturated ECVI showed good fit .

FIT Incremental Measures

Tucker-Lewis Index or Non-normed Fit Values ranged from 0-1, with higher Index (TLI or NNFI) values are better. TLI $\geq 0.90$ is a good fit, while $\leq 0: 08$ TLI $<0.90$ was marginal fit . 


\begin{tabular}{|c|c|}
\hline Normed Fit Index (NFI) & $\begin{array}{l}\text { Values ranged from } 0-1 \text {, with higher } \\
\text { values are better. NFI } \geq 0.90 \text { is a good } \\
\text { fit, while } \leq 0: 08 \text { NFI }<0.90 \\
\text { was marginal fit. }\end{array}$ \\
\hline Adjusted Goodness of Fit Index (AGFI) & $\begin{array}{l}\text { Values ranged from } 0-1 \text {, with higher } \\
\text { values are better. AGFI } \geq 0.90 \text { is a good } \\
\text { fit, while } \leq 0: 08 \text { AGFI }<0.90 \\
\text { was marginal fit. }\end{array}$ \\
\hline Relative Fit Index (RFI) & $\begin{array}{l}\text { Values ranged from } 0-1 \text {, with higher } \\
\text { values are better. RFI } \geq 0.90 \text { is a good } \\
\text { fit, while } \leq 0: 08 \text { RFI }<0.90 \\
\text { was marginal fit. }\end{array}$ \\
\hline Incremental Fit Index (IFI) & $\begin{array}{l}\text { Values ranged from } 0-1 \text {, with higher } \\
\text { values are better. IFI } \geq 0.90 \text { is a good } \\
\text { fit, while the IFI } \leq 0: 08<0.90 \\
\text { was marginal fit. }\end{array}$ \\
\hline Comparative Fit Index (CFI) & $\begin{array}{l}\text { Values ranged from } 0-1 \text {, with higher } \\
\text { values are better. CFI } \geq 0.90 \text { is a good } \\
\text { fit, while the CFI } \leq 0: 08<0.90 \\
\text { was marginal fit. }\end{array}$ \\
\hline \multicolumn{2}{|l|}{ FIT PARSIMONIOUS Measures } \\
\hline $\begin{array}{r}\text { Parsimonious } \\
\text { index }(\mathrm{PGFI})\end{array}$ & $\begin{array}{l}\text { The specification of GFI, where a higher } \\
\text { value indicates a greater parsimony, this } \\
\text { measure is used for comparisons } \\
\text { between models. }\end{array}$ \\
\hline Normed Chi-Square & $\begin{array}{l}\text { The ratio between the Chi-Square } \\
\text { divided degree of freedom. Suggested } \\
\text { value: lower limit } 1.0 \text {, the upper limit of } \\
2.0 \text {, or } 3.0 \text { and looser } 5.0\end{array}$ \\
\hline Parsimonious normed Fit Index (PNFI) & $\begin{array}{l}\text { A high value indicates a better match, } \\
\text { only used for comparisons between } \\
\text { alternative models. }\end{array}$ \\
\hline Akaike Information Criterion (AIC) & $\begin{array}{l}\text { Smaller positive value indicates better } \\
\text { parsimony, used for comparisons } \\
\text { between models. In a single model, AIC } \\
\text { value of the model approaches } \\
\text { the saturated AIC shows good of fit. }\end{array}$ \\
\hline $\begin{array}{l}\text { Consistent Akaike } \\
\text { Criterion (CAIC) }\end{array}$ & $\begin{array}{l}\text { Smaller positive value indicates better } \\
\text { parsimony, used for comparisons } \\
\text { between models. In a single model, } \\
\text { CAIC value of the model approaches } \\
\text { the saturated CAIC shows good of fit. } \\
\text { R GOFI }\end{array}$ \\
\hline Critical "N" (CN) & $\begin{array}{l}\mathrm{CN} \geq 200 \text { indicates sufficient sample } \\
\text { size to be used to estimate a satisfactory } \\
\text { model of compatibility or good. }\end{array}$ \\
\hline
\end{tabular}




\section{ANALYSIS AND RESULT}

\section{a. Validity Analysis of Measurement Model}

1. Check out the t-value

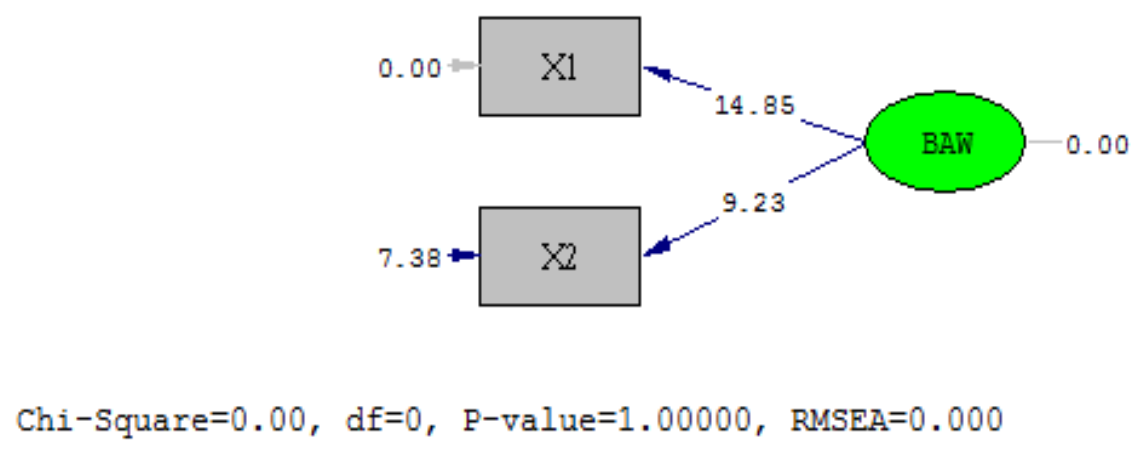

Figure 1. Path Brand Awareness (t- value

Source: Output LISREL 8.80 Processed Researcher

Based on the results output LISREL 8.80 above can be seen that the measurement equation for the coefficient of Brand Awareness of each indicator has a $t$-value $\geq 1.96$, which means that the indicators Brand Awareness all valid and statistically significant with a significance level of $5 \%$. and there should be no discharge indicator.

\section{Checking the value of the standardized loading factor $(\lambda)$}

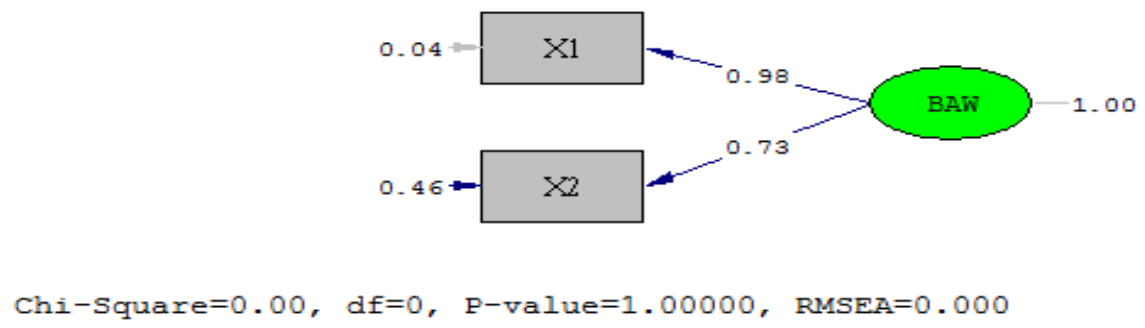

Figure 2. Path Brand Awareness (Standardized Solution)

Source: Output LISREL 8.80 Processed Researcher

Based on the above figure can be seen that the standardized loading factor $(\lambda)$ variable indicator of the most dominant in the variable Brand Awarenessis X1 or the statement

"Recognition" as seen from the value of the standardized loading factor of 0.98 .

b. Compatibility Test Measurement Model

Output lisrel Goodness of Fit Brand Awareness 
Degrees of Freedom $=0$

Fit Function Minimum Chi-Square $=0.0(\mathrm{P}=1.00)$

Normal Weighted Least Squares Theory Chi-Square $=0.00(\mathrm{P}=1.00)$

The model is Saturated, the Fit is Perfect!

Source: Output LISREL 8.80 Processed Researcher

Based on the results of the LISREL output above we can see that the model measured showed a perfect match ( Perfect fit ) because all indicators of goodness of fit (GOF) has a value corresponding to its range.

\section{c. Analisis Realibility Model}

Table 1. Reliability Brand Awareness

\begin{tabular}{|c|c|c|c|c|c|c|}
\hline \multirow[t]{2}{*}{ Indicator } & \multirow[t]{2}{*}{ SLF } & \multirow[t]{2}{*}{ Error } & \multicolumn{4}{|c|}{ construct Reliability } \\
\hline & & & $\overline{\Sigma S L F}$ & $\sum(\mathrm{SLF})^{2}$ & Serror & value $\mathrm{CR}$ \\
\hline \multicolumn{7}{|c|}{ brand Awareness } \\
\hline $\mathrm{X} 1$ & 0.98 & 0.04 & 1.71 & 2.92 & 0.51 & 0.85 \\
\hline $\mathrm{X} 2$ & 0.73 & 0.47 & & & & \\
\hline
\end{tabular}

Source: Output LISREL 8.80 Processed Researcher

According Hair (1998), good reliability requirement is if it has a value of Construct Reliability $\geq 0.70 .4: 13$ of calculation in the table above, it can be seen that the value of the construct reliability overall in Brand Awareness is 0.85> 0.70. This shows that the reliability of these measurements both the model and construct Brand Awareness is supported by the data obtained.

\section{Latent Brand Associate}

\section{a. Validity Analysis of Measurement Model}

1. Check out the t-value

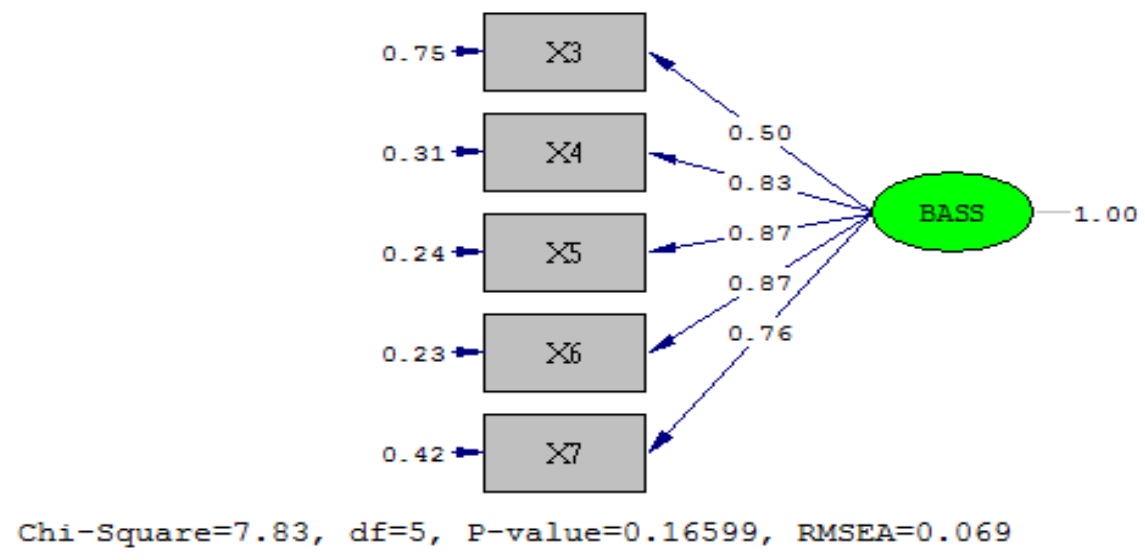

Figure 3. Path Brand Assosiate (t-value)

Source: Output LISREL 8.80 Processed Researcher

Based on the results output LISREL 8.80 above can be seen that the measurement equation for the coefficient Brand Associate at each indicator has a $t$-value $\geq 1.96$, which 
means that the indicators Brand Associate at all valid and statistically significant with a significance level of $5 \%$. and there should be no discharge indicator.

2. Checking the value of the standardized loading factor $(\lambda)$

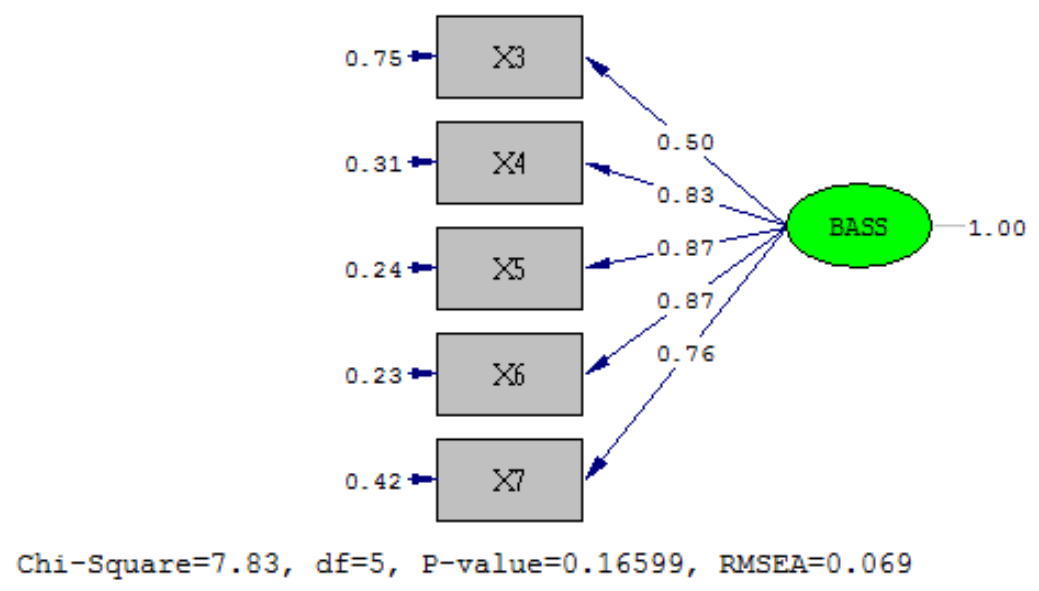

Figure 4. Path Brand Associate (Standardized Solution)

Based on the above figure can be seen that the standardized loading factor $(\lambda)$ variable indicator of the most dominant in the variable Brand Associateis X5 and X6 or the statement "uniqueness" and "relevance" as seen from each have the value of the standardized loading factor of 0,87 .

\section{b. Compatibility Test Measurement Model}

Table 2. Goodness of Fit Brand Associate

\begin{tabular}{lccc}
\hline \multicolumn{1}{c}{ size GoF } & \multicolumn{1}{c}{$\begin{array}{c}\text { Value } \\
\text { Statistics Chi Square }\left(\chi^{2}\right)\end{array}$} & $\begin{array}{c}\text { level Compatibility } \\
\text { Good Fit }\end{array}$ \\
\cline { 1 - 2 } $\begin{array}{l}\text { Standardized Root Mean Square } \\
\text { Residuan (SRMR) }\end{array}$ & 0028 & & Good Fit \\
$\begin{array}{l}\text { Root Mean Square Error of } \\
\text { Approximation }\end{array}$ & 0.069 & & Good Fit \\
(RMSEA) & & & \\
Non-normed Fit Index (NNFI) & 0.99 & Good Fit \\
Normed Fit Index (NFI) & 0.98 & Good Fit \\
Relative Fit Index (RFI) & 0.97 & Good Fit \\
Incremental Fit Index (IFI) & 0.99 & Good Fit \\
Comparative Fit Index (CFI) & 0.99 & Good Fit \\
\hline
\end{tabular}

Source: Output LISREL 8.80 Processed Researcher

According to the table above we can see that the value SRMR is 0028, this value is in the range of less than 0.05 , which means it is a good fit. Chi Square value into the category 
of Good fit because its value is less than the threshold. NNFI, NFI, IFI and CFI all worth> 0.90 , this means that everything can be categorized as good a fit as well as the value of RMSEA less than 0:08. So, overall it can be concluded that the model measured showed a good fit ( good fit).

Hypothesis testing. As already described in previous chapters, in this study there are 9 (five) hypothesis on direct influence. Analysis of hypothesis testing is performed with a significance level of $5 \%$, resulting in a critical $t$-value of \pm 1.96 . The hypothesis is accepted if the $t$-value obtained $\geq 1.96$, while the hypothesis is not supported if the obtained t-value $<1.96$. The following is a table of the overall hypothesis testing to answer the following questions:

Table 3. Hypothesis Testing Research Model H1-H9

\begin{tabular}{|c|c|c|c|c|}
\hline Hypothesis & Statement & T-Count & T-Table & Information \\
\hline $\mathrm{H}_{1}$ & Brand Awareness to Brand Preference & 2,27 & \multirow{9}{*}{1.96} & significant \\
\hline $\mathrm{H}_{2}$ & Brand Assosiate to Brand Preference & 3.73 & & significant \\
\hline $\mathrm{H}_{3}$ & Brand Extension to Brand Preference & 3.61 & & significant \\
\hline $\mathrm{H}_{4}$ & $\begin{array}{l}\text { Perceived quality to Customer } \\
\text { Satisfaction }\end{array}$ & 2.33 & & significant \\
\hline $\mathrm{H}_{5}$ & $\begin{array}{l}\text { Brand Awareness on Customer } \\
\text { Satisfaction }\end{array}$ & 2.74 & & significant \\
\hline $\mathrm{H}_{6}$ & $\begin{array}{l}\text { Brand Assosiate to Customer } \\
\text { Satisfaction }\end{array}$ & 3.11 & & significant \\
\hline $\mathrm{H}_{7}$ & $\begin{array}{l}\text { Brand Extension on Customer } \\
\text { Satisfaction }\end{array}$ & 3.82 & & significant \\
\hline $\mathrm{H}_{8}$ & $\begin{array}{l}\text { Perceived quality to Customer } \\
\text { Satisfaction }\end{array}$ & 2.02 & & significant \\
\hline $\mathrm{H}_{9}$ & $\begin{array}{l}\text { Brand Preference towards Customer } \\
\text { Satisfaction }\end{array}$ & 3.19 & & significant \\
\hline
\end{tabular}

Effect of Direct, Indirect and Total. Analysis of the effect of direct, indirect and total used to see the effect of inter-constructs. The direct effect is the coefficient of all the lines with arrows one end. The indirect effect is the effect that arises through intermediate variable. While the total effect is the effect of the various relationships, the effect of direct, indirect and total based on the image below:

Figure 4. Structural Model (standardized Solution)

\begin{tabular}{cccc}
\hline Variable & Direct Impact & Indirect Influence & Total \\
\hline BAW - KP & 0.20 & 0.058 & 0.258 \\
BASS -KP & 0.22 & 0.058 & 0.278 \\
BEX -KP & $0: 31$ & $0: 009$ & $0: 319$ \\
PQ -KP & 0.15 & $0: 061$ & $0: 211$ \\
\hline
\end{tabular}

Source: Output LISREL 8.80 Processed Researcher

From the output of LISREL 8.80 for the structural model (Standardized Solution), the following is a table of the effect of direct, indirect and total processed researchers: 


\section{DISCUSSION AND CONCLUSION}

Brand Extension to the Customer Satisfaction. Variable brand extension has a direct effect by $31 \%(0.31)$ to customer satisfaction, the higher knowledge of advertisers on the network and information on Sindo Media, the customer satisfaction with the brand holding higher. In line said by Keller (2003) which says that the brand extension is consistent with the parent brand image, it will increase customers' confidence in the parent brand. Customers / advertisers who feel the impact of advertising on Sindo Media in accordance with what is expected is a positive thing, look at the table total effect, that the brand extension has a high impact on customer satisfaction which is the total of the effects of direct and indirect amounted to 31.9\% (0319).However, the variable of brand extension has no direct influence on customer satisfaction brokered brand Preference magnitude is very small at $0.9 \%$ (0009). In this study indicate that the brand preferences of Sindo Media considered still low, which resulted in the tendency of advertisers to choose specific brand / other media that have the same network (extension ). If a brand preference in this study is high, then customer satisfaction Sindo Media brands will be higher as well.In this study indicate that the brand preferences of Sindo Media considered still low, which resulted in the tendency of advertisers to choose specific brand / other media that have the same network (extension). If a brand preference in this study is high, then customer satisfaction Sindo Media brands will be higher as well.In this study indicate that the brand preferences of Sindo Media considered still low, which resulted in the tendency of advertisers to choose specific brand / other media that have the same network (extension ). If a brand preference in this study is high, then customer satisfaction Sindo Media brands will be higher as well.

\section{b. Brand Associate to Customer Satisfaction}

Brand assosiate have a direct impact on customer satisfaction by $22 \%(0: 22)$, the higher the degree of brand association Sindo then the satisfaction of advertisers towards brand Sindo also higher. The indirect effect of brand associate brokered brand Preference for 5:08\% (0.0508), meaning that the brand Preference shown by Sindo Media is quite low, so the effect on customer satisfaction Sindo Media, the same opinion expressed by Hellier, et al: 2003 expressed a preference brand is factors that influence consumers to choose a brand that will be selected based on consideration of one of them is the attributes shown by the brand.Advertisers in choosing the media would do a variety of specific considerations to determine which media are selected. Things look different from the effects which the value of the overall total being built larger construct that is equal to $27.8 \%$ (0278).

\section{c. Brand Awareness against Customer Satisfaction}

Brand awareness is based on the results of the tables are processed by the researchers showed a value of $20 \%$ (0.20), the higher the awareness created by the company the customer satisfaction will also be higher. While the indirect effect of brandawareness has the same value as the brand associate is 5:08\% (0.0508), meaning that the brand awareness of Sindo has the awareness is low, so Preference is also low and the effect on customer satisfaction / advertiser. According (Hellier, et al: 2003 in Margareth,2008) said the brand Preference is one level of brand awareness, or brand already on the top of mind of consumers, in this case the researchers assessed Sindo Media still has the awareness that is lower than that of the parent brand MNC Media. The net effect is constructed from whole construct has a value of $25.8 \%$ (0258) and is lower than the brand associate, it can be said that the awareness of Sindo Media is very less.in this case the researchers assessed Sindo Media still has the awareness that is lower than that of the parent brand MNC Media. The net effect is constructed from whole construct has a value of $25.8 \%$ (0258) and is lower than the brand associate, it can be said that the awareness of Sindo Media is very less.in this case the researchers assessed Sindo Media still has the awareness that is lower than that of the parent brand MNC Media. The net effect is constructed from whole construct has a 
value of $25.8 \%$ (0258) and is lower than the brand associate, it can be said that the awareness of Sindo Media is very less.

\section{d. Perceived quality to Customer Satisfaction}

Perceived quality is customer ratings for the quality of goods / services, while the results of this study indicate that the perceived quality has a direct impact is smaller than the other variables, the value of the effect of perceived quality by $15 \%(0: 15)$ on customer satisfaction shows that perceived quality, the higher the top-quality services and products will be higher the customer satisfaction. While the indirect effect of perceived quality is higher than other variables, namely $6.1 \%$ (0061), is not directly perceived quality of high coupled with high brand preference will also affect customer satisfaction.Perceived quality with regard to what is expected by the customer, and is highly subjective and brand preference by (Samadi: 2007, in Zahran Kashanizadeh: 2014) is the consumer confidence of product attributes that will affect the attitude of consumers towards the brand, which in turn encourages behavioral tendencies, In this study, researchers looked advertisers choose brand Sindo Media factors or attributes that are inside one of them is by bundling media (integration) so that the brandSindo Media can convince and encourage advertisers tend to advertise in Sindo than competitors kind and feeling of satisfaction with the service and products provided.The total effect of the construct formed by $21.1 \%(0,211)$ and is smaller than the value Paing other variables.

\section{BIBLIOGRAPHY}

Aaker, David A, . (1991). Managing Brand Equity, New York: The Fee Press

Aaker, David A. (1996). Building Strong Brands, New York: The Fee Press

Albarra, Alan B.(1996). Media Economic, Market Understanding, Industry, and Concepts. Iowa: Iowa State University Press.

Ananda Putri Widya (2015). the Ad Spending Still Growing, the SWA [internet], Available from: < http://swa.co.id/business-research/semester-i2015-belanja-iklan-masih- can-grow > [access 20 January 2016].

Anggi Oktarinda (2014). Listening Future Media Print, Bisnis Indonesia [internet], Available from: < http://industri.bisnis.com/read/20140613/105/235735/menyimak-masa-depanmedia-massa -cetak > [access 20 January 2016].

Ardhanari, Margaretha (2008). "Customer Satisfaction Effect on Brand Preference and Repurchase Intention Private Brand", Journal of Economics and Business Research, Vol 8 No. 2, [access to 22 November 2015]

Cecep Supriadi (2014). Build and manage Brand Equity, Marketing [Internet], Available from: $<$ http://www.marketing.co.id/membangun-dan-mengelola- brand-equity/> [access 09 March 2016]

Darmadi Durianto, Sugiarto, Tony Sitinjak. (2004). Strategy Conquer the Markets: Through the Brand Equity Research and Behavior, Jakarta: PT. Gramedia Pustaka Utama.

D. Till, Brian., Daniel Baack, Brian Waterman, (2011). "Strategic Brand Association Maps: Developing Brand Insight", Journal of Product and Brand Management, 2 (2), (access 26 april 2015)

Dimmick, John W. (2003). Media Competition and Coexistence The Theory of the Nich . London: Lawrence Erlbaum Associates Publisers.

Dwivedi, Abhishek., Bill Merrilees, (2013). Brand extension feedback effects: towards a Mediated framework, 30 (5), 450-461, (access to 26 November 2015).

Dwi, Afrilianti (2011). Sindo Media Launched, MNC Group Makin Complete [Internet], Available from: http://news.okezone.com/read/2011/10/19/337/517386/Sindo-media-diluncurkan-mnc -group-more-complete (access October 10, 2015) 
Fayrene YL, Chieng, Goi Chai Lee, (2011). Customer- Based Brand Equity: A Literature Review, Vol II, Issue-I, (access 26 April 2015).

Fill, Chris, (2009). Marketing Communication (interactivity, communities and content) fifth edition, England: Pearson Education Limited

Ferdinand, Augusty, (2006). Research Methods Management, 2nd Edition, Semarang: Diponegoro University Publishers Agency.

(2006). Structural Equation Modeling in Management Research, Applications Elaborate Models In Research For Masters and Doctoral Dissertation Thesis, Semarang: Diponegoro University Publishers Agency

Grant, augut E. Wilkinsont, Jeffrey S, (2009). Undestanding Media Convergence, New York: Oxford University Press,

Hui Wang, Ya., (2014). Journal of Applied Finance and Banking, 4 (5), 69-81. (Access 02 november 2015).

Juwandi, Hendy Irawan., (2004). Satisfaction Services . Jakarta: Erland

Kashanizadeh, Zahra. Mohammad Rahim Esfidani, (2014). A survey on antecedents of brand Preference (A case of Samsung on Audio and Video products), 3 (4), 882-891, (access November 2, 2015).

Kotler, Philip, (2009). Marketing Management Volume I (Indonesian edition), Jakarta: PT.Erlangga , (2007). Marketing Management Volume II (Indonesian edition ), Jakarta: PT. Index.

Lupiyoadi, Creep, (2013). Marketing Management Services, Jakarta: Four Salemba

McQuail, Dennis, (2002). Theory of Mass Communication, An Introduction, Jakarta: PT. Erland.

Rangkuti, Freddy. (2002). The Power of Brands , Jakarta: PT. Gramedia Pustaka Utama

Ropesta Sitorus (2015). Nielsen Survey: Print From Abandoned The Advertiser. Bisnis Indonesia [internet], Available from: < http://industri.bisnis.com/read/20150819/12/463673/surveynielsen-media-cetak-mulai-ditinggalkan-para-pengiklan > [Access 20 januari 2016] ,

Saviq Bachdar (2015). proved Word of Mouth is a Powerful Campaigns, Marketeers [internet], Available from: http://marketeers.com/article/terbukti-word-of-mouth-adalah-promosi-yangampuh.html [access 10 March 2016].

Sendjaja, Sasa Djuarsa. (1993). Introduction to Communication Studies, Jakarta: The Open University.

Shahroodi, Hamed Mohammadi, Hossein Kaviani, Mohammad Reza Abasian, 2015, Evaluating the Effect of Brand Equity on Consumer Satisfaction and Brand Loyalty in Large Retails of the Mazandaran Province (Case Study: Food Products Industry), Vol.4, No.1 [access 20 november 2015].

Sigit Kurniawan (2015). Media Ad Spending in Indonesia Tends to Rise, Marketeers [internet], Available from: http://marketeers.com/article/belanja-iklan-media-di-indonesia-cenderungnaik.html (Access 20 January 2016).

Sigit Kurniawan (2015). competition is not between the stations TV but Antarkonten, Marketeers [internet], Available from: < http://marketeers.com/article/persaingan-bukan-antarstasiun-tvtapi-antarkonten.html > [20 januari access 2016].

Sigit Kurniawan (2016). The Last Year, Total Advertising Expenditure Government Rp. 73 Trillion, Marketeers [internet], Available from: http://marketeers.com/article/tahun-lalutotal-belanja-iklan-pemerintah-rp-73-triliun.html [access 16 March 2016]

Simamora, Bilson, (2002). Alloy Research Consumer Behavior, Jakarta: PT. Gramedia Pustaka

Straubhaar, Y and La Rose, R (2006). Media Now: Comunications Media in The Informations Informations Age. Second Edition. Belmont: CA Wadswort.

Yunita, Irma. (2012). "Effect of Service Quality, Product Quality and Brand Image Loyalty Advertisers PT. Radar Banten and Competitors". Thesis, University of Indonesia Esa Unggul. 